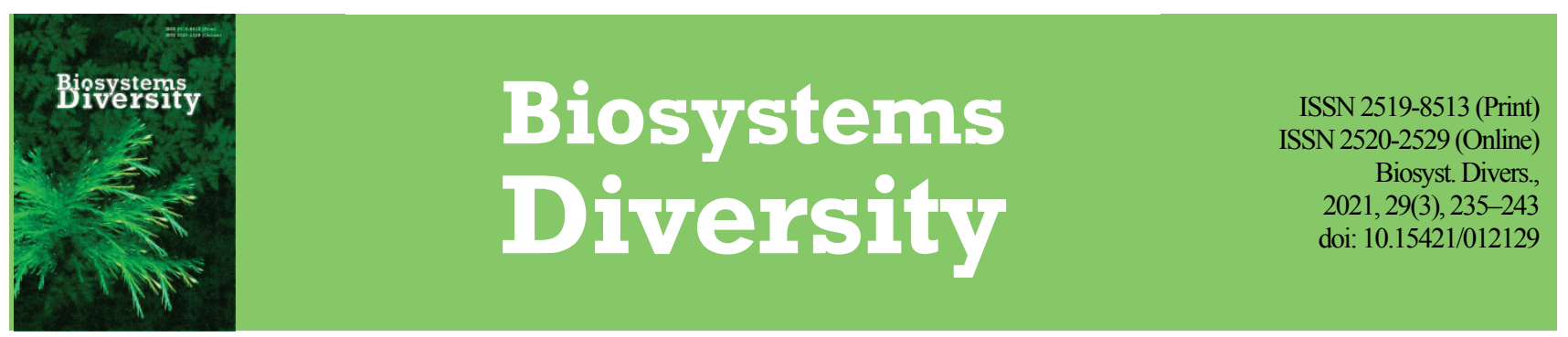

\title{
Soluble curcumin ameliorates motility, adhesiveness and abrogate parthanatos in cadmium-exposed retinal pigment epithelial cells
}

\author{
V. S. Nedzvetsky*, **, V. Y. Gasso*, C. A. Agca**, E. V. Sukharenko*** \\ *Oles Honchar Dnipro National University, Dnipro, Ukraine \\ **Bingöl University, Bingöl, Turkey \\ ***Kerch State Maritime Technological University, Kerch, Ukraine
}

Article info

Received 17.06.2021

Received in revised for

Oles Honchar Dnipro National

University, Gagarin Ave., 72,

Dnipro, 49010, Ukraine.

Tel.: +38-099-783-33-25.

E-mail:nedzvetskyvictor@ukr.net

Bingöl University,

Selahaddin-i Eyyubi Mah.

Üniversite Cad. No 1 ,

Bingöl, 12000, Turkey.

Tel.: +90-505-975-12-82.

E-mail:nedzvetskyvictor@ukr.net

Kerch State Maritime Technological University, Ordzhonikidze Ave., 82

Kerch, 98309, Ukraine.

Tel. +79-788-20-00-25.

E-mail:helenasuhar@gmail.com

\author{
Nedzvetsky, V. S., Gasso, V. Y., Agca, C. A., \& Sukharenko, E. V. (2021). Soluble curcumin ameliorates motility, adhesiveness \\ and abrogate parthanatos in cadmium-exposed retinal pigment epithelial cells. Biosystems Diversity, 29(3), $235-243$. \\ doi:10.15421/012129
}

Cadmium $(\mathrm{Cd})$ is a nonessential transition metal and one of the most toxic environmental pollutants. Industrial, agricultural and urban activities are the main sources of Cd environmental contamination. Multiple deleterious effects of $\mathrm{Cd}$ exposure were reported for different cell types and living organisms in a great number of research papers. $\mathrm{Cd}$ bioaccumulation hazard is mediated by the relatively long half-life of this metal in an organism. For example, in mammals its half-life lasts for about 10-30 years. Cd exposure affects many tissues. However, some of them, including the central nervous system and sensory organs, are most susceptible to its toxicity. The harmful effects of $\mathrm{Cd}$ could be linked to oxidative stress generation and consequently intracellular signalling disruption. Since $\mathrm{Cd}$ induces redox imbalance the antioxidants could be a prospective tool to ameliorate Cd cytotoxicity. In present work, we have studied the protective efficacy of soluble curcumin on Cd-caused retinal pigment epithelium (RPE) cells viability, reactive oxygen species production, adhesive and extracellular matrix proteins expression, cell migration and parthanatos level. Low dose $(5 \mu \mathrm{M})$ of soluble curcumin ameliorated all aforementioned indices of Cd-induced cytotoxicity. Curcumin has restored the RPE cells motility as well as fibronectin and E-cadherin expression. Therefore, the modulation of RPE adhesiveness could be regarded as a cytoprotective effect of curcumin. Furthermore, Cd-caused poly(ADP-ribose) polymerase-1 (PARP-1) suppression and cleaved PARP-1 upregulation were ameliorated by curcumin exposure. Therefore, the protective effect of soluble curcumin could be related, at least partially, to the modulation of PARP activity and inhibition of parthanatos flux. The observed results have demonstrated that low doses of soluble curcumin are a promising tool to protect RPE cells against Cd-caused retinal injury.

Keywords: heavy metal; ecotoxicology; biomarkers; PARP-1; Nrf2; fibronectin; E-cadherin; turmeric extract.

\section{Introduction}

Cadmium $(\mathrm{Cd})$ is a nonessential transition metal that was confirmed to be one of the most toxic environmental pollutants according to the Agency for Toxic Substance and Disease Registry (ATSDR) ranking (ATSDR, 2017). Furthermore, $\mathrm{Cd}$ is enormously represented in all natural areas where humans and animals can potentially be affected by its exposure. Bioabsorbance of $\mathrm{Cd}$ is caused by multiple sources, namely polluted ground and surface waters, batteries, industrial wastes, contaminated food, paints, tobacco smoking, etc. (Van Maele-Fabry et al., 2016; Cornet et al., 2018).

A large body of recent data demonstrates that the harmful effect of $\mathrm{Cd}$ may include irreversible disturbances in molecular pathways and cellular functioning. Various manners of $\mathrm{Cd}$ substances can be regarded as inductors of different abnormalities in key pathways into the vital organs (Järup \& Akesson, 2009; Nair et al., 2013; Ninkov et al., 2015). Significant variation in the deleterious effects of $\mathrm{Cd}$ in mammalian tissues was reported (Swiergosz-Kowalewska, 2001). Based on biochemical and molecular alterations, the cells of the liver and kidney are recognized as the most sensitive to Cd cytotoxicity among all the tissues and organs (Järup \& Akesson, 2009; Ninkov et al., 2015). Nevertheless, together with the well-studied $\mathrm{Cd}$-induced toxicity in the liver and kidney, evidence has been found that $\mathrm{Cd}$ exposure can induce extremely detrimental complications in neural tissue cells (Baiomy \& Mansour, 2016; Branca, 2018; Piludo et al., 2019). Tissue-specific susceptibility to Cd cytotoxicity correlates with its cumulative proprieties. Furthermore, $\mathrm{Cd}$ bioaccumulation is accompanied by the relatively long half-life of $\mathrm{Cd}$ that lasts about $10-30$ years in humans (Fujiwara et al., 2012). The high range of $\mathrm{Cd}$ absorbance and bioaccumula- tion in the brain were detected as similar with regard to liver and kidney. (Wang \& Du, 2013). Therefore, neural tissue cells are one of priority targets of $\mathrm{Cd}$ cytotoxic effects. While undetermined molecular mechanisms of $\mathrm{Cd}$ toxicity in the liver and kidney have reported, the neurotoxic effect of low doses of $\mathrm{Cd}$ is presented in a limited number of reports. In spite of the data on Cd neurotoxicity in children published in the 1970 1980s, the brain as a critical target of Cd exposure has received little attention since then (Pihl \& Parkes, 1977; Thatcher et al., 1982; Marlowe et al., 1983).

Taking into account the broad environmental and industrial distribution of $\mathrm{Cd}$ compounds, $\mathrm{Cd}$ accumulation in vital tissues and multiple deleterious effects on the fundamental pathways, the study of molecular mechanisms of Cd-dependent cellular pathology is extremely relevant to construct a therapeutic strategy (Branca, 2018; Piludo et al., 2019). The known mechanisms of Cd cytotoxicity include imbalance in intracellular calcium turnover, the stress of endoplasmic reticulum, disturbance in mitochondria-mediated pathways of cell death regulation (Nilesh et al., 2009; Branca, 2018). In addition, Cd exhibits an affinity to glutathione and leads to downregulation of this most crucial antioxidant in the neural tissue. It was reported that $\mathrm{CdSO}_{4}$ initiates glutathione depletion and cell death in the primary astrocytes culture (Im et al., 2006).

The multiple toxic effects of $\mathrm{Cd}$ in various cell types could be related to the oxidative stress generation as the most studied mechanism similar to other heavy metal ions (Farina et al., 2013). Cd induces reactive oxygen species (ROS) production indirectly through the suppression of antioxidant systems, including superoxide dismutase, catalase and glutathione peroxidase with similar manner in different cell types (Shukla et al., 1989; 
Acan \& Tezcan, 1995). In addition, Cd inhibits non-enzyme antioxidant defence as well (Tian et al., 2011). Once absorbed, Cd exhibits different cytotoxicity depending on cell type and intracellular distribution. One of the most detrimental effects of Cd is the genotoxicity that includes inhibition of DNA synthesis, proliferation and differentiation, cell cycle arrest and suppression of DNA repair (Giaginis et al., 2006; Rani et al., 2014; Luo et al., 2020). Taken together, all of them cause a genome instability and dysregulation in gene expression. Another Cd-induced abnormality is the upregulation of inflammatory cytokines. Exposure to Cd leads to multifaceted impairments accompanied by both oxidative stress generation and pro-inflammatory changes in the neural tissue cells (Phuagkhaopong et al., 2017).

$\mathrm{Cd}$ neurotoxicity to the sensory organs draws special interest due to the direct communication with central neural system (CNS). The vision is one of the most critical sensory functions of mammals. Recent findings on heavy metal content in the human retina have shown that $\mathrm{Cd}$ is one of prior candidates to be an inducer of retinal pathogenesis of age-related macular degeneration (Pamphlett et al., 2020). Furthermore, the retinal cells accumulate $\mathrm{Cd}$ (Wills et al., 2009). The retina has a complex structure and contains neural, glial and epithelial cell types that provide eyesight functions. Recently, one of the specialized cell types in retina - retinal pigment epithelial (RPE) cells - was recognized as susceptible to $\mathrm{Cd}$ poisoning (Kalariya et al., 2009; Branca, 2018). The RPE cells provide the neural retina with metabolites and play a critical role in retinal regeneration (BarbosaSabanero et al., 2012). However, the effect of $\mathrm{Cd}$ on the sensory organs including retina and its protection strategy remain studied insufficiently.

Natural antioxidants were confirmed to be promising tools to ameliorate heavy metals toxicity. The efficacy of antioxidants to prevent molecular damage and to protect cell viability was demonstrated in different cell types including pituitary and liver tissues (Poliandri et al., 2003; Tandon et al., 2003). The suppression of ROS production in RPE cells exposed to $\mathrm{Cd}$ was demonstrated with $\mathrm{N}$-acetylcysteine administration (Kalariya et al., 2009). However, up to this date the well-known antioxidant curcumin has not been used in practice to treat Cd-caused disturbances in the retina. Curcumin is one of the most extensively studied cytoprotective agents in recent decades. The efficacy of curcumin has been shown in liver cells damaged by hepatotoxic heavy metals including lead, mercury, cadmium, chromium, and copper (García-Niño \& Pedraza-Chaverrí, 2014). Curcumin (diferuloylmethane or 1,7-bis[4-hydroxy-3-methoxyphenyl]-1,6-heptadiene-3,5-dione) is a natural polyphenol extracted from the rhizome of Curcuma longa Linnaeus, 1753. Curcumin known as turmeric is widely used as a dietary spice throughout the world (Aggarwal et al., 2007; Basnet \& Skalko-Basnet, 2011). Curcumin exhibits multiple bioactive features including antioxidant (Al-Jassabi et al., 2012; Mohajeri et al., 2017), antiviral (Kutluay et al., 2008), antimicrobial (Tajbakhsh et al., 2008), anti-inflammatory (Bereswill et al., 2010), and anti-tumour activities (Wang et al., 2009; Huang et al., 2013). The detected cytoprotective effect of curcumin is associated with the inhibition of lipid peroxidation and the maintenance of glutathione level (Strasser et al., 2005). In addition, curcumin activates antioxidant enzymes, prevents mitochondrial dysfunction and suppresses production of the pro-inflammatory cytokines through transcriptional control in both transformed and normal cell types (Fattori et al., 2015; Tong et al., 2016). Taking into account that $\mathrm{Cd}$ induces oxidative stress associated with the pro-inflammatory changes, application of curcumin could be an adequate strategy to mitigate Cd-related disturbances. In spite of vigorous cytoprotective features, curcumin exhibits poor bioavailability due to its low level of water solubility (Priyadarsini, 2014). Despite its hydrophobic property, modern approaches allow producing water-soluble curcumin formulations that can easily overcome biomembranes and biobarriers (Purkayastha et al., 2009). In the present study, we used the water-soluble fraction of natural curcumin to develop a model of RPE cells cytoprotection with low doses of curcumin. There are many reports on curcumin cytoprotection in different tissues; however, the efficacy of applying it to Cd-affected retinal cells remains unknown.

The objective of our work was to elucidate the changes in the migration capability, transcriptional regulation and DNA repair induced with low doses of Cd in RPE primary astrocyte cell culture and to evaluate the protective effect of curcumin.

\section{Materials and methods}

The human RPE cell line was obtained from American Type Culture Collection (Cat\#CRL2302, ATCC, Rockwille, MD). The RPE cells were cultivated in Dulbecco's modified Eagle medium/Hams F-12 50/50 Mix (DMEM/F12) medium containing 10\% foetal bovine serum (FBS), 1000 $\mathrm{U} / \mathrm{mL}$ penicillin and streptomycin, $25 \mathrm{mM}$ glucose, $1 \%$ L-glutamine, $1 \%$ sodium pyruvate. The cells were collected with trypsin/EDTA solution when the confluence was $80-90 \%$. The cells $\left(5 \times 10^{5}\right)$ were transferred to $6 \mathrm{~cm}$ Petri dish and growth-arrested with $0.2 \%$ FBS containing medium 24 hours before experiment. The RPE cells were subjected to $10 \mu \mathrm{M}$ cadmium chloride $\left(\mathrm{CdCl}_{2}\right)$, water-soluble curcumin fraction in doses 2 and $5 \mu \mathrm{M}$ and aforementioned doses of $\mathrm{Cd}$ with curcumin together for $48 \mathrm{~h}$. When curcumin was used to treat Cd-exposed RPE cells, the cells were pre-incubated with curcumin for $1 \mathrm{~h}$ before the treatment with $\mathrm{Cd}$.

The concentrations of the tested substances were selected based on the earlier published literature data (Kalariya et al., 2009; Mori et al., 2015; Lee et al., 2016). Stock solution of $\mathrm{CdCl}_{2}$ was prepared by dissolving in DMEM at $100 \mathrm{mM}$ and stored in $-20^{\circ} \mathrm{C}$. Curcumin stock solution was prepared by dissolving curcumin water-soluble fraction (Curcumin L-WS E-100, Sensient Technologies Corporation, the USA) in DMEM at $4 \mathrm{mM}$ right before treatment. All chemicals except curcumin were obtained from Sigma-Aldrich. The migration activity of RPE cells was determined using wound-healing assay to clarify functional disorders induced by $\mathrm{Cd}$ exposure as well as cytoprotective effect of curcumin against $\mathrm{Cd}$ cytotoxicity. The RPE cells $\left(7 \times 10^{5}\right)$ were inoculated to 6 -wells plates with DMEM/F12 medium containing 10\% FBS. When the cell growth had achieved $100 \%$ confluence, the gap in their colony was made by scratching with using a pipet's $200-\mu \mathrm{L}$ tip. The cells had been rinsed with phosphate buffer saline (PBS) to remove detached cells and were incubated with DMEM F12 medium containing 0.2\% FBS. Cell treatment with $\mathrm{Cd}$ or/and curcumin was performed in the same manner as mentioned above. The photographs were taken every 24 hours with invert microscope (Olympus CKX41, Olympus Corporation, Japan).

The level of cell viability was determined by measuring the capability of live cells to reduce 3-(4,5-dimethylthiazol-2-yl)-2,5-diphenyltetrazolium bromide (MTT assay) The individual effects of $\mathrm{Cd}$ and curcumin as well as cytoprotective effect of curcumin in Cd-exposed RPE cells on cell viability were studied for $48 \mathrm{~h}$ treatment. Cells were gathered from $90 \%$ confluence flask using trypsin/EDTA solution, centrifuged and calculated. Cell pellet was suspended in DMEM containing $10 \%$ FBS and diluted to concentration $10^{5}$ cells $/ \mathrm{mL}$. The RPE cells $\left(10^{4}\right.$ cells/well $)$ were inoculated into 96-well plates in DMEM/F12 medium containing 10\% FBS and incubated for 12 hours in $37^{\circ} \mathrm{C}$ in a humidified atmosphere with $5 \% \mathrm{CO}_{2}$. After cell attachment and the start of the growth, the medium was changed in every well and the cells were exposed to $\mathrm{Cd}(10 \mu \mathrm{M})$ and curcumin dissolved as described above. Control (untreated) cells were not exposed to any solution. Every control and $\mathrm{Cd}$, curcumin and $\mathrm{Cd}+$ curcumin exposed concentration was represented by 3 wells and replicated twice. The medium was removed from plates after $48 \mathrm{~h}$ incubation and the wells were rinsed with PBS. After washing with the saline buffer PBS, the cells were incubated in the solution containing $180 \mu \mathrm{L}$ PBS and $20 \mu \mathrm{L}$ MTT reagent. The incubation with MTT reagent was carried out for $4 \mathrm{~h}$ at $37^{\circ} \mathrm{C}$ in a humidified atmosphere with $5 \% \mathrm{CO}_{2}$. After incubation, MTT solution was removed and $180 \mu \mathrm{L}$ DMSO was added to each well for the followed $10 \mathrm{~min}$ incubation. The absorbance level was measured at $570 \mathrm{~nm}$ length wave in the presence of $20 \mu \mathrm{L}$ Sorensen's buffer. The obtained data were presented as the percentage of control value.

The production of intracellular general forms of ROS was determined with 2',7'-dichlorofluorescin diacetate (DCFHDA). Control and exposed cells were rinsed with PBS, treated with $10 \mu \mathrm{M}$ DCFHDA and incubated for $30 \mathrm{~min}$ in $37^{\circ} \mathrm{C}$. The ROS levels were determined using a SpectraMax Gemini EM spectrofluorometer with $485 \mathrm{~nm}$ wavelength excitation and $530 \mathrm{~nm}$ emission.

The control and curcumin cells exposed to $\mathrm{Cd}$ after 48 hour treatment were washed in Petri dishes trice with the cold PBS and collected by scratching without trypsinization. The collected cells were centrifuged and lysed in RIPA buffer containing proteinase and phosphatase inhibitor cocktail. The PRE cell proteins were extracted for $60 \mathrm{~min}$ at $4{ }^{\circ} \mathrm{C}$. After 
lysis, the cell extracts were centrifuged at $40,000 \mathrm{~g}$ for $20 \mathrm{~min}$. The content of total protein in supernatants was measured with spectrophotometer by the Bradford method using BSA as the standard (Bradford, 1976). The supernatant of each protein extract was mixed with LaemmLi sample buffer containing $0.1 \mathrm{M}$ dithiothreitol in ratio 1:1 and boiled for $5 \mathrm{~min}$. Protein samples fixed with LaemmLi buffer were frozen and stored at -80 ${ }^{\circ} \mathrm{C}$ before the start of the western blot analysis.

The proteins were separated using polyacrilamide gel (PAG) electrophoresis using 5-20\% gradient of acrylamide and then the proteins were transferred from gel onto polyvinylidene fluoride (PVDF) membrane with application of the electric field $(10 \mathrm{~V} / \mathrm{cm})$. After the transfer, PVDF membrane was rinsed and blocked in $1 \%$ bovine serum albumin (BSA) in PBS-Tween-20 solution. The blocked membrane was probed overnight at $4{ }^{\circ} \mathrm{C}$ to primary antibodies anti-Nrf2 (1:2000, Abcam, ab137550), antiPARP (1:3000, Abcam, ab32071), anti-fibronectin (1:2000, Abcam, ab199056), anti-E-cadherin (1:2000, Abcam, ab40772) and anti-GAPDH as a loading control (1:2500, Santa Cruz, sc-365062) antibodies. After the primary antibodies incubation, the membrane was washed and incubated with corresponding secondary either anti-rabbit or anti-mouse IgG antibodies conjugated with horseradish peroxidase (1:20000, Abcam, ab6721) were used to probe the membrane after primary antibodies. Immunostaining was developed with luminol-hydrogen peroxide solution by the enhanced chemiluminescence method with the use of X-ray films (Konica Minolta, Japan). Densitometric analysis of the immunostained polypeptide zones was performed using TotalLab TL120 software (USA). The intensity value obtained with scanning every individual band was normalized to the intensity in respect with correspondent actin band. Every track on the scanned picture was corrected to background level, which corresponds to nonreactive area on the X-ray film.

Statistical comparisons of the data were performed using a one-way analysis of variance (ANOVA) followed by Tukey's post-hoc test using Origin, 2019 (OriginLab Corporation, the USA). The data are expressed as the mean (M) with standard error (SEM) of at least four independent experiments. $P$ values less than 0.05 were considered statistically significant. The graphs were constructed using GraphPad Prism 9 (GraphPad Software, the USA).

\section{Results}

In order to detect the effects of Cd on cell viability, the RPE cells were exposed to $1,2,5 \mu \mathrm{M}$ curcumin and $10 \mu \mathrm{M} \mathrm{CdCl}_{2}$ for $48 \mathrm{~h}$. The progressive decline in cell viability was observed in the RPE cells treated with 5 and $10 \mu \mathrm{M} \mathrm{CdCl}_{2}$. These doses reduced cell viability by $82 \%(\mathrm{P}<0.05)$ and $64 \%(\mathrm{P}<0.01)$ respectively. The dose of $10 \mu \mathrm{M}$ as a concentration, which initiates prominent cytotoxicity, was selected to investigate the cytoprotective effect of low doses of curcumin.

Curcumin slightly suppressed cell viability in the dose of $5 \mu \mathrm{M}$. On the other hand, the cytoprotective effect of curcumin was observed in Cd-exposed RPE cells. Cd-induced decline in cell viability was significantly $(\mathrm{P}<0.01)$ prevented by $5 \mu \mathrm{M}$ curcumin administration (Fig. 1 ).

Similar curcumin effect was detected for the suppression of ROS level in both 2 and $5 \mu \mathrm{M}$ doses in Cd-exposed RPE cells. The exposure of untreated RPE cells to curcumin had no effect on the ROS production while the curcumin inhibited the ROS upregulation in Cd-exposed RPE cells in a dose-dependent manner (Fig. 2).

Cell migration plays a critical role in the repairing different damages to replace the injured cells. Cell migration is regulated by intercellular and cell-extracellular matrix (ECM) adhesion. The estimation of migration capability using wound-healing assay showed significant inhibitory effect of Cd exposure on the RPE cells moving activity. According to the obtained cell viability results, Cd-caused suppression was ameliorated with the curcumin administration (Fig. 3).

The content of nuclear factor erythroid-2 related factor 2 (Nrf-2) was studied to clarify a possible curcumin role in the transcriptional regulation of the RPE cell response against $\mathrm{Cd}$ cytotoxicity. The upregulation of $\mathrm{Nrf}-2$ was observed in Cd-exposed RPE cells. The treatment with curcumin caused no changes in Nrf-2 content in the control untreated cells. However, the application of $5 \mu \mathrm{M}$ curcumin significantly inhibited the increase in Nrf-2 expression (Fig. 4).

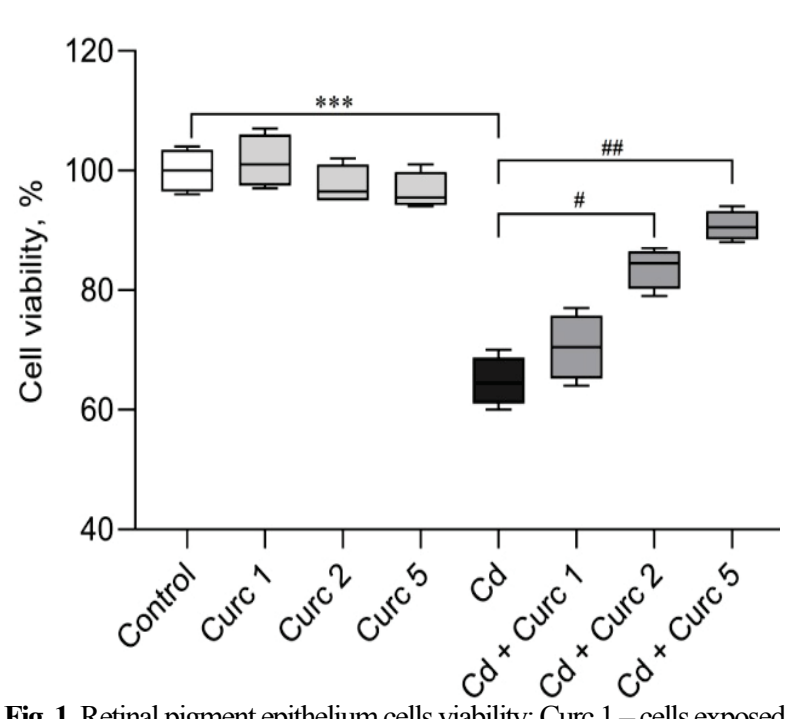

Fig. 1. Retinal pigment epithelium cells viability: Curc 1 - cells exposed to $1 \mu \mathrm{M}$ curcumin, Curc 2 - exposed to $2 \mu \mathrm{M}$ curcumin, Curc 5 - to $5 \mu \mathrm{M}$ curcumin, $\mathrm{Cd}$ - to $10 \mu \mathrm{M} \mathrm{CdCl}_{2}, \mathrm{Cd}+\mathrm{Curc} 1$ - to $1 \mu \mathrm{M}$ curcumin + $10 \mu \mathrm{MCdCl}_{2}, \mathrm{Cd}+$ Curc 2 - to $2 \mu \mathrm{M}$ curcumin $+10 \mu \mathrm{M} \mathrm{CdCl}_{2}$, $\mathrm{Cd}+$ Curc 5 - cells exposed to $5 \mu \mathrm{M}$ curcumin $+10 \mu \mathrm{M} \mathrm{CdCl}_{2}$; data expressed as $\mathrm{x} \pm \mathrm{SE} ; * * *-\mathrm{P}<0.001$ (compared with control group), ${ }^{\#}-\mathrm{P}<0.01,{ }^{\#}-\mathrm{P}<0.001$ (compared with $\mathrm{Cd}$ exposed group)

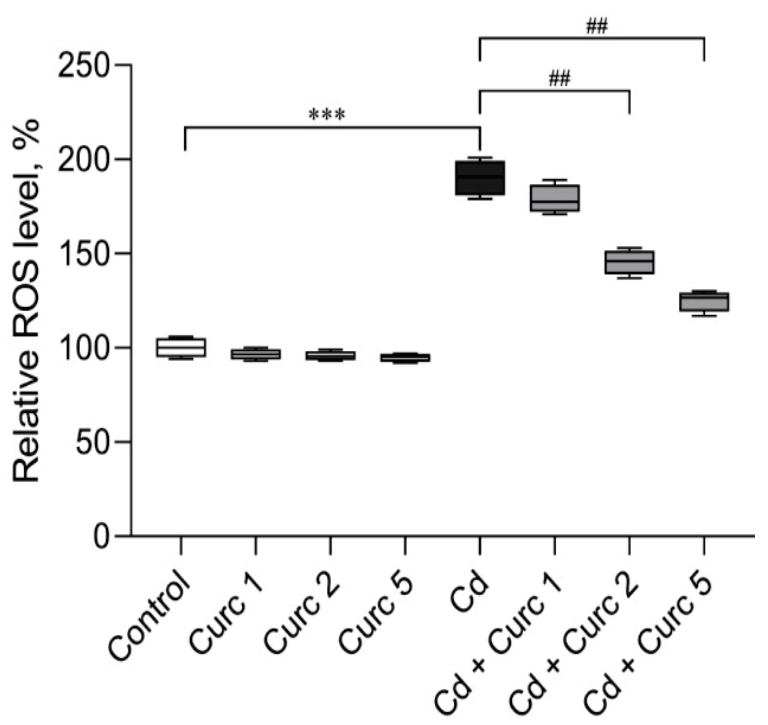

Fig. 2. Reactive oxygen species (ROS) level in retinal pigment epithelium cells: Curc 1 - cells exposed to $1 \mu \mathrm{M}$ curcumin, Curc 2 - exposed to $2 \mu \mathrm{M}$ curcumin, Curc 5 - to $5 \mu \mathrm{M}$ curcumin, $\mathrm{Cd}$ - to $10 \mu \mathrm{M} \mathrm{CdCl}_{2}$, $\mathrm{Cd}+\mathrm{Curc} 1-$ to $1 \mu \mathrm{M}$ curcumin $+10 \mu \mathrm{M} \mathrm{CdCl}_{2}, \mathrm{Cd}+\mathrm{Curc} 2-$ to $2 \mu \mathrm{M}$ curcumin $+10 \mu \mathrm{M} \mathrm{CdCl}_{2}, \mathrm{Cd}+\mathrm{Curc} 5$ - cells exposed to $5 \mu \mathrm{M}$ curcumin $+10 \mu \mathrm{M} \mathrm{CdCl}_{2}$; data expressed as $\mathrm{x} \pm \mathrm{SE} ; * * *-\mathrm{P}<0.001$ (compared with control group), ${ }^{{ }^{\prime}}-\mathrm{P}<0.01$ (compared with Cd exposed group)

The measuring of extracellular matrix (ECM) protein fibronectin and epithelial adhesive protein E-cadherin has shown a statistically significant decrease $(\mathrm{P}<0.01)$ of them both in Cd-exposed RPE cells. Curcumin administration ameliorated a downregulation of both fibronectin and Ecadherin in a similar manner (Fig. 4).

The expression of PARP was studied in the present work to elucidate Cd-caused disturbance in the DNA repair mechanism depending on polyADP-ribose synthesis by this enzyme. The treatment with $10 \mu \mathrm{M} \mathrm{CdCl}_{2}$ induced statistically significant increase in $89 \mathrm{kDa}$ PARP-cleaved subunit. At the same time, curcumin in the dose of $5 \mu \mathrm{M}$ promoted restoration of the level of PARP initial content as in the intact cells (Fig. 4).

The results of western blot (Fig. 5) and wound healing assay suggest the involvement of adhesive protein E-cadherin and ECM protein fibronectin into the Cd-dependent downregulation of the cell migration. 

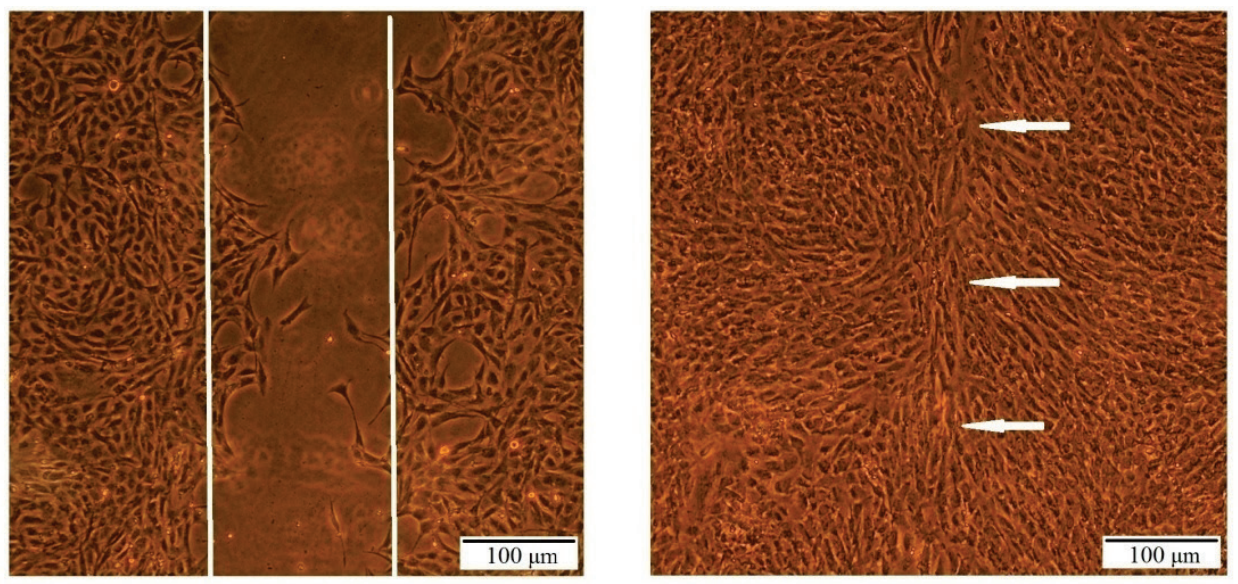

Control
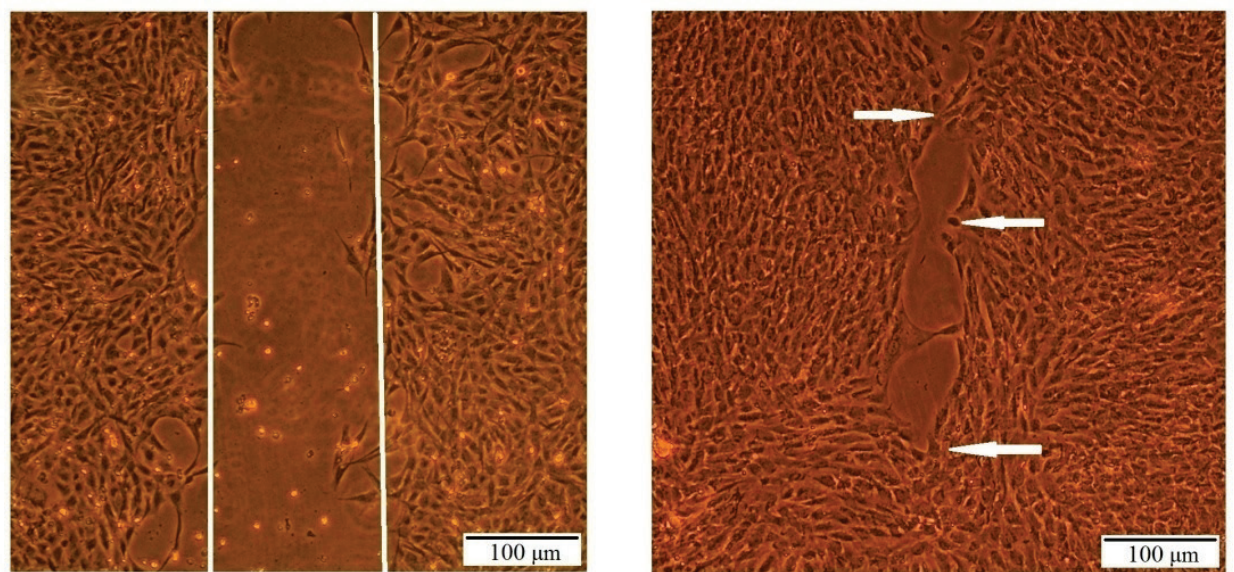

Curcumin 5
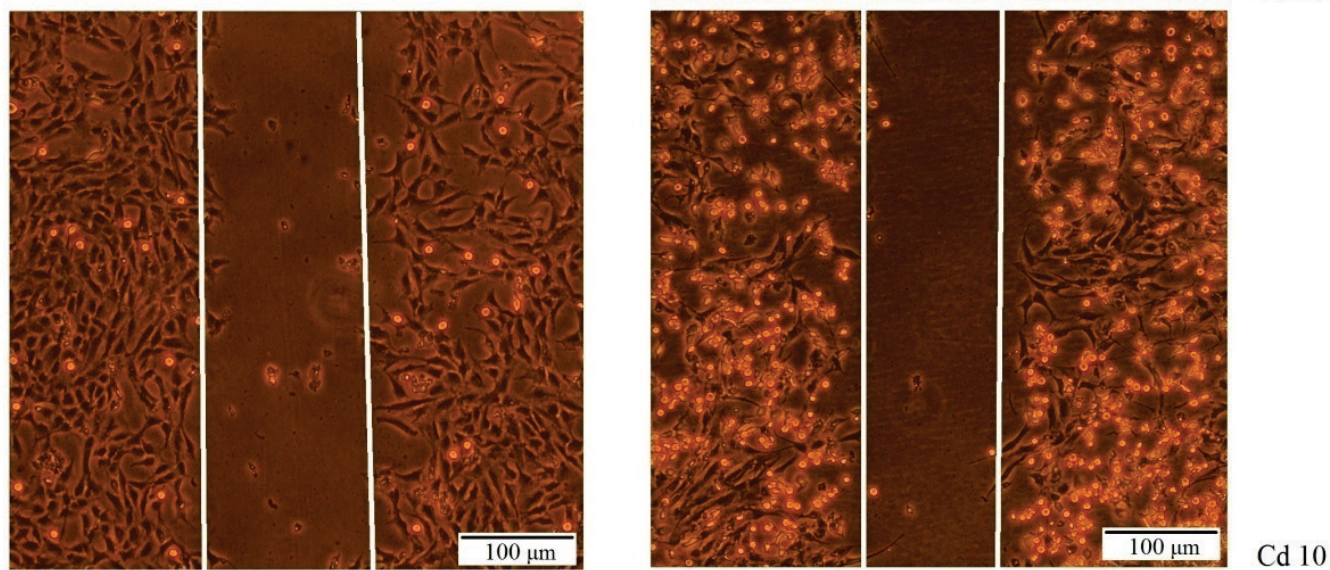

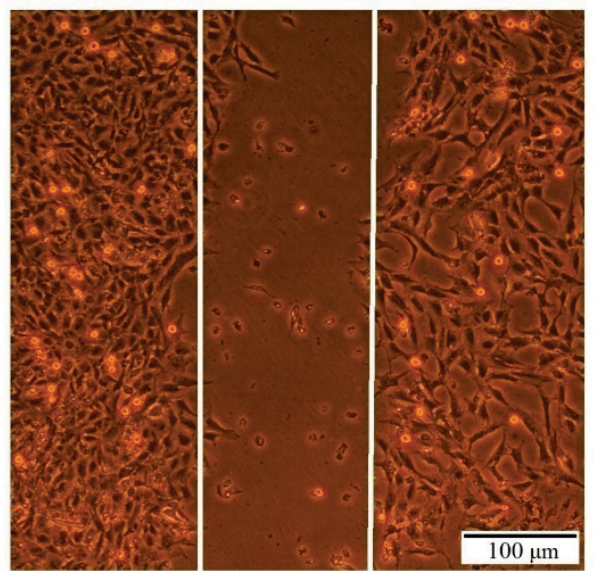

Start time of exposure, $0 \mathrm{~h}$

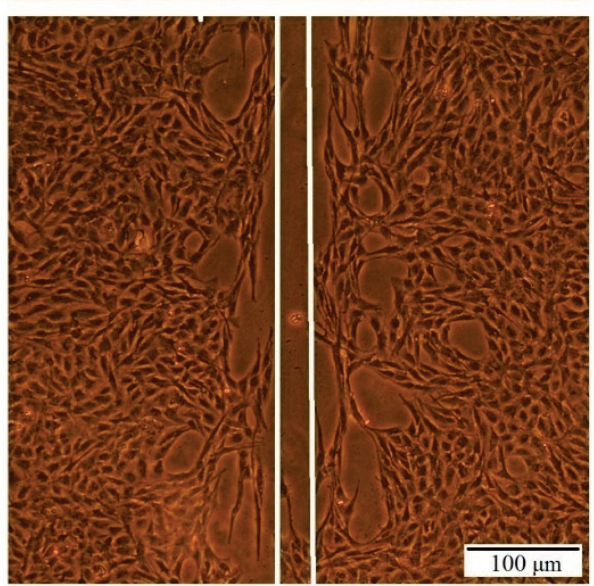

Finish time of exposure, $84 \mathrm{~h}$

Fig. 3. Wound healing assay of retinal pigment epithelium cells immediately $(0 \mathrm{~h})$ and $84 \mathrm{~h}$ after performing a scratch: Curcumin 5 - cells exposed to $5 \mu \mathrm{M}$ curcumin, $\mathrm{Cd} 10$ - cells exposed to $10 \mu \mathrm{M} \mathrm{CdCl}_{2}, \mathrm{Cd} 10+$ Curcumin 5 - cells exposed to $10 \mu \mathrm{M} \mathrm{CdCl}_{2}$ and $5 \mu \mathrm{M}$ curcumin; the gaps are indicated with white lines; the closed gaps are indicated with white arrows 

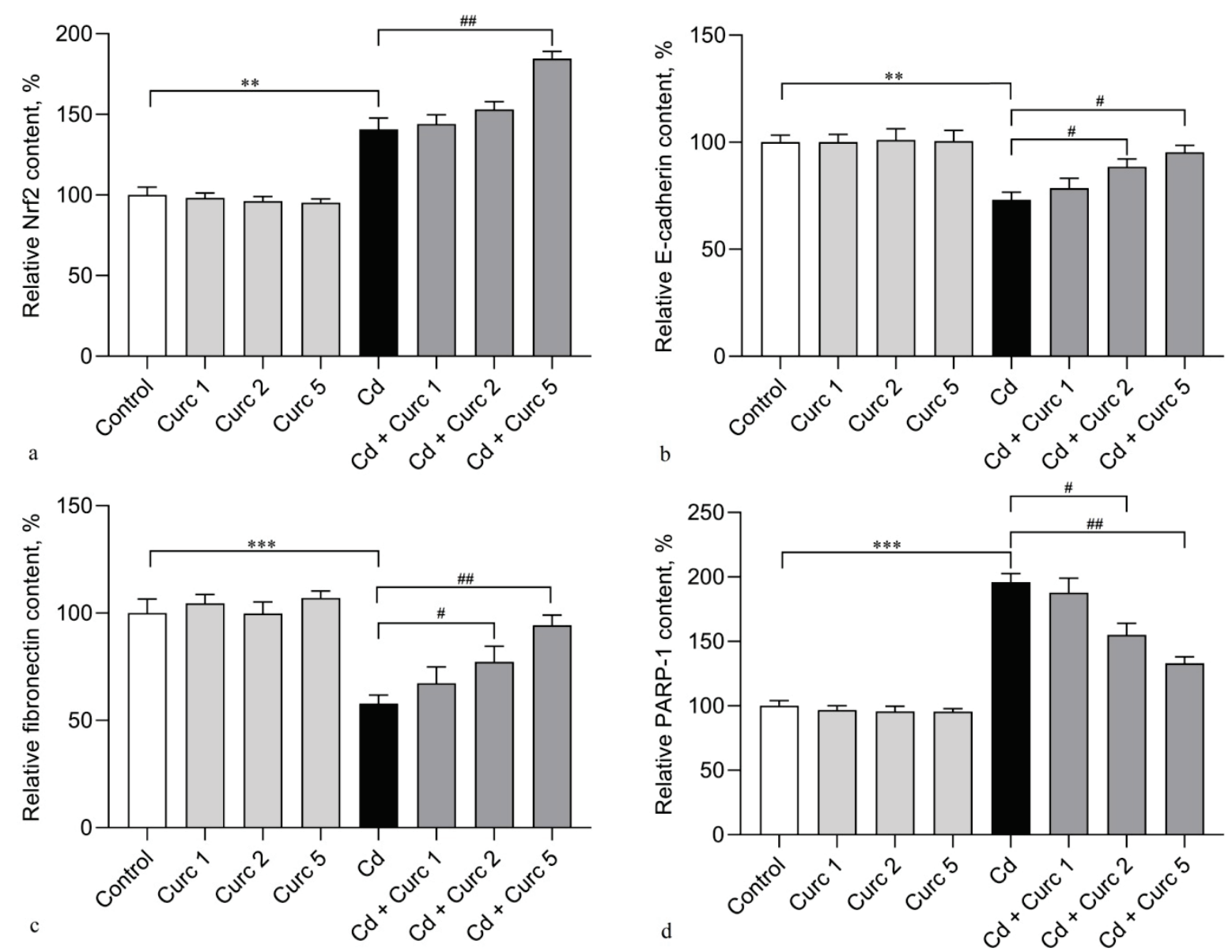

Fig. 4. The Nrf2 (a), E-cadherin $(b)$, fibronectin $(c)$ and PARP-1 $(d)$ in retinal pigment epithelium cells: Curc 1 - cells exposed to $1 \mu \mathrm{M}$ curcumin, Curc 2 - exposed to $2 \mu \mathrm{M}$ curcumin, Curc 5 - to $5 \mu \mathrm{M}$ curcumin, $\mathrm{Cd}$ - to $10 \mu \mathrm{M} \mathrm{CdCl}_{2}, \mathrm{Cd}+\mathrm{Curc} 1$ - to $1 \mu \mathrm{M}$ curcumin $+10 \mu \mathrm{MCdCl}_{2}$, $\mathrm{Cd}+\mathrm{Curc} 2-$ to $2 \mu \mathrm{M}$ curcumin $+10 \mu \mathrm{M} \mathrm{CdCl}_{2}, \mathrm{Cd}+\mathrm{Curc} 5$ - cells exposed to $5 \mu \mathrm{M}$ curcumin $+10 \mu \mathrm{M} \mathrm{CdCl}_{2}$; data expressed as $\mathrm{x} \pm \mathrm{SE}$; ${ }^{* *}-\mathrm{P}<0.01,{ }^{* *}-\mathrm{P}<0.001$ (compared with control group); ${ }^{\#}-\mathrm{P}<0.05,{ }^{\ldots}-\mathrm{P}<0.01$ (compared with Cd exposed group)

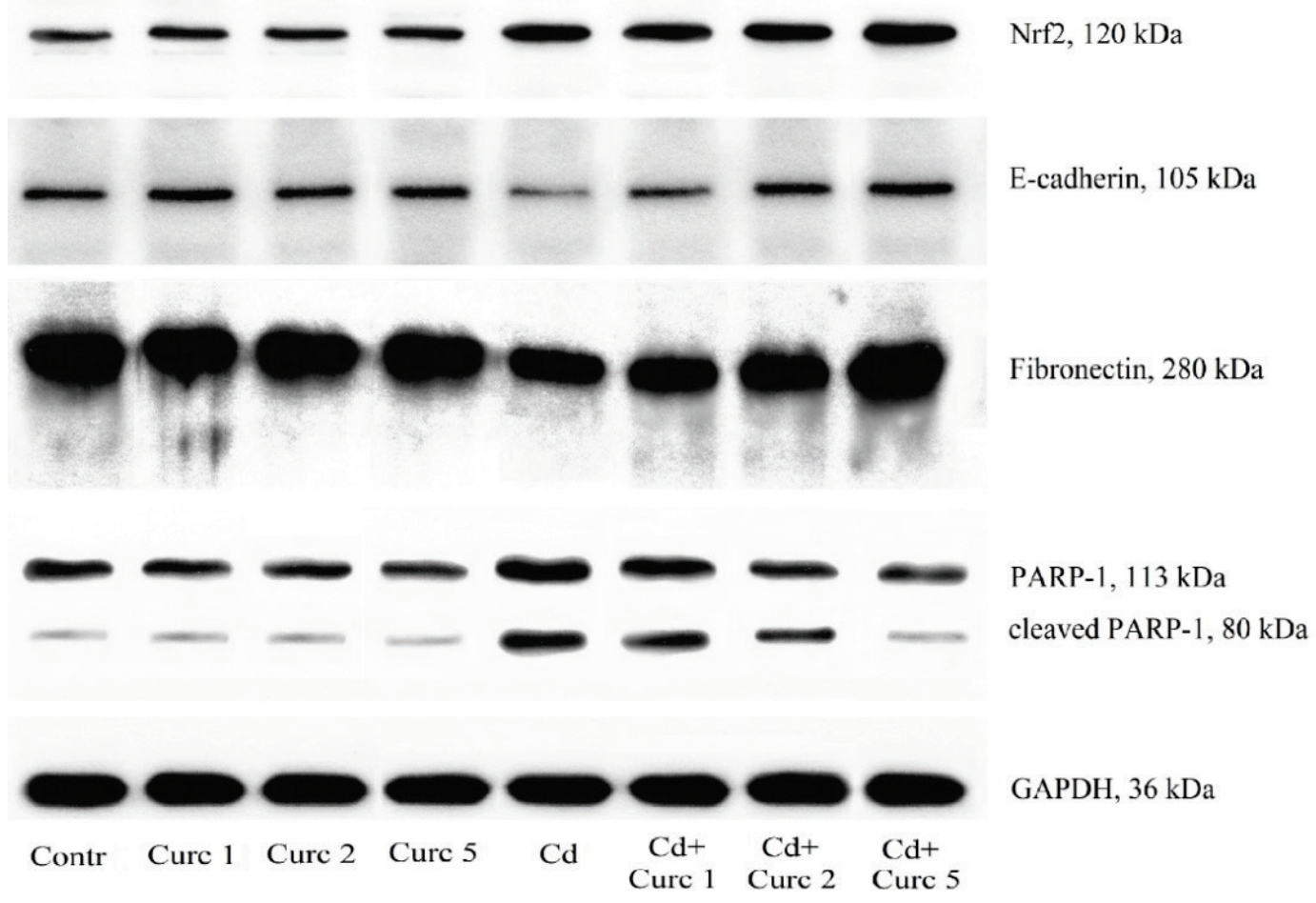

Fig. 5. Western blot analysis of Nrf2, E-cadherin, fibronectin, PARP-1 and GAPDH: Contr - control group, Curc 1 - cells exposed to $1 \mu \mathrm{M}$ curcumin, Curc 2 - exposed to $2 \mu \mathrm{M}$ curcumin, Curc 5 - to $5 \mu \mathrm{M}$ curcumin, $\mathrm{Cd}$ - to $10 \mu \mathrm{MCdCl}_{2}, \mathrm{Cd}+\mathrm{Curc} 1$ - to $1 \mu \mathrm{M}$ curcumin $+10 \mu \mathrm{MCdCl}_{2}$, $\mathrm{Cd}+\mathrm{Curc} 2-$ to $2 \mu \mathrm{M}$ curcumin $+10 \mu \mathrm{M} \mathrm{CdCl}_{2}, \mathrm{Cd}+\mathrm{Curc} 5$ - cells exposed to $5 \mu \mathrm{M}$ curcumin $+10 \mu \mathrm{M} \mathrm{CdCl}_{2}$ 
The data obtained bear evidence for the prospective potential of curcumin administration for the amelioration of Cd-caused disturbance in $\mathrm{E}$ cadherin and fibronectin expression and protection of the migration function.

\section{Discussion}

Molecular mechanisms of curcumin cytoprotection. The mechanisms of curcumin cytoprotection were reported in several models of heavy metal toxicity including aluminium, Cd and lead (García-Niño \& Pedraza-Chaverrí, 2014; Mohajeri et al., 2017; Kar et al., 2019). Recently, protective antioxidant effect of curcumin was detected in serum of mice treated with cadmium (Momeni \& Eskandari, 2020). In addition, the efficacy of curcumin against $\mathrm{Cd}$ toxicity was shown in several reports. For instance, the neuroprotection and hippocampal neurogenesis promotion were demonstrated in mice CNS (Namgyal et al., 2020). Furthermore, the glioprotection in cultured primary astrocytes was confirmed in respect to glial cytoskeleton and energy metabolism (Nedzvetsky et al., 2018; Namgyal et al., 2020). Nevertheless, the cytoprotective effect of soluble curcumin on Cd-induced retinal damages remains unknown.

Therapeutic efficacy of curcumin was verified in a number of studies and is related to the control molecular signaling pathways, which in turn modulate cell survival and cellular response to cytotoxic agents (Hatcher et al., 2008). Natural curcumin has a low bioavailability and exhibits antiproliferative activity in high $(10-50 \mathrm{M})$ doses towards malignant cells. Besides, $10 \mathrm{M}$ dose was reported as cytoprotective of retinal neurons (Wang et al., 2011). However, several cell types including RPE cells are susceptible to the effects of curcumin. A decrease was determined in cell viability and VEGF secretion in RPE cells exposed to curcumin in doses above $10 \mu \mathrm{M}$ (Hollborn et al., 2013). Therefore, the curcumin doses that are effective in inhibiting the neuronal cell death have adverse effects on RPE cells. In the present work, we have studied respectively low doses (1-5 M) of soluble curcumin to protect RPE cells against $\mathrm{Cd}$ cytotoxicity.

The effect of curcumin on Cd-caused oxidative stress, cell viability and the transcriptional factor Nrf2 expression. There is limited data on $\mathrm{Cd}$ toxicity effects in the retina. The recent findings on heavy metal content in the human retina have shown that $\mathrm{Cd}$ is one of the prior candidates to be an inducer of retinal pathogenesis in the age-related macular degeneration (AMD) (Pamphlett et al., 2020). Oxidative stress and apoptosis were confirmed as undoubted Cd-caused abnormalities in retinal cells (Kalariya et al., 2009; Kletner 2012). Cd-induced apoptosis in human ARPE-19 cells is initiated with the caspase 3 activation and causes the loss of cell viability (Chen et al., 2008). However, the exact mechanisms of Cd-caused cytotoxicity remain poorly understood. The activation of mitogen activated protein kinase (MAPK) and inhibition of protein phosphatases were reported as the disturbances, accompanied by neuronal apoptosis and oxidative stress (Chen et al., 2008). There was seen a link between $\mathrm{Cd}$ accumulation in human retina and progress in AMD (Wills et al., 2009). Recently, endoplasmic reticulum (EPR) stress and autophagy flux were detected in RPE cells exposed to Cd (Zhang et al., 2019). The authors concluded that these abnormalities play a pivotal role in AMD and blindness.

$\mathrm{Cd}$ is confirmed as a ROS upregulating agent in various tissues including the retina (Klettner, 2012; López-Malo et al., 2020). Oxidative stress is one of the most studied initiators of the progress in retinal pathogenic changes, in which both destructive and repairing molecular mechanisms are involved. In conjunction with molecular damage, oxidative stress generates the signalling of cellular response aimed at supporting the cell survival. For instance, ROS-dependent phosphatidylinositide 3-kinase (PI3K) activation is a part of intracellular signalling and leads to the initiation of cellular response against toxic agents via $\mathrm{PI} 3 \mathrm{~K} / \mathrm{Nrf} 2 / \mathrm{HO}-1$ pathway (Wang et al., 2018). Furthermore, the role of many factors involved in this response to oxidative stress and associated complications are diverse and conflicting. Several protein kinases may conduct both protective and apoptotic pathways. The decline in RPE cells viability and upregulation of ROS production, which we observed in our study, are coherent with earlier published results on the dose-dependent manner of $\mathrm{Cd}$ toxicity (Kalariya et al., 2009; Zhang et al., 2019). Furthermore, the role of oxidative stress in retinal pathology was confirmed by applying $\mathrm{N}$-acetylcystei- ne as an antioxidant to prevent Cd-caused retinal damage (Zhang et al., 2019). Another aspect of oxidative stress impact in retinal pathogenesis was studied in the retina of human donor eyes. The decrease in Nrf-2 and hemoxigenase-1 (HO-1) transcript levels was observed in the retina of human donor eyes with AMD associated changes (Aberami et al., 2019). Nrf-2 and HO-1 are the parts of antioxidant defence and their depletion leads to increase in oxidative stress.

The mild increase in Nrf-2 content found in our study can be related to the low dose and short-term Cd exposure. Moreover, some data evidence that $\mathrm{Cd}$ low doses activate the cell response and metabolic activity as was demonstrated in astrocytes and neuronal cells (Gulisano et al., 2009; Phuagkhaopong et al., 2017). Therefore, we may assume that the results observed in Cd-exposed RPE cells upregulation of Nrf-2 are a part of defensive response against increased ROS production and multifaceted $\mathrm{Cd}$ toxicity. In the present study, we have shown that $\mathrm{Cd}$-caused retinal cell death exhibits a dose-dependent manner accompanied by defensive response initiation. Our results are consistent with Cd-dependent disturbances that were reported for the neuronal cells (Chen et al., 2008).

Curcumin administration had no changes in ROS level, cell viability and Nrf2 content in untreated control cells. However, in Cd-exposed RPE cells curcumin in the dose of $5 \mu \mathrm{M}$ inhibited both the ROS upregulation and the cell viability decrease. Furthermore, curcumin induced a significant increase in Nrf2 expression. Nrf2 controls HO-1 expression transcriptionally and in this manner mediated cell response against toxicity. Thus, one of possible mechanisms of the protective effect of curcumin could be mediated with Nrf2-dependent transcriptional regulation of antioxidant defence including HO-1.

The effect of curcumin on Cd-caused cell motility and adhesion. Cell migration is a fundamental process to repair damaged areas and support tissue functions. The suppression of RPE cells migration can suspend the retinal repair as well as the vision function. The disruption of the mechanisms that provide cell migration was studied in TM4 Sertoli cells treated with 1 and $12 \mu \mathrm{M} \mathrm{CdCl}_{2}$ for $4 \mathrm{~h}$ (Egbowon et al., 2016) and in endothelial ECV-304 cell line exposed to $1-5 \mu \mathrm{M} \mathrm{CdCl}_{2}$ for $24 \mathrm{~h}$ (Kolluru et al., 2006). Also, Liu and co-authors reported that $\mathrm{Cd}$ does not affect proliferation and migration of lung cancer A549 cells at concentrations of 0.1-10 $\mu \mathrm{M}$ (Liu et al., 2015). On the other hand, there was shown the Cddependent activation of migration capability of breast cancer MDA-MB231 cells (Wei \& Shaikh, 2017). The similar effect of chronic Cd exposure was observed in the breast non-cancer epithelial cell lines (MCF10A) and in the hTERT gene containing human pancreatic nestin expressing cells (hTERTHPNE) (Vanlaeys et al., 2020). Therefore, contradictory effect of $\mathrm{Cd}$ depends on the cell type as well as the total duration and dosage.

The inhibitory effect of Cd on RPE cell migration observed in the present study could reflect Cd-caused multiple harmful effect. A lack of migration ability as a result of $\mathrm{Cd}$ exposure was recognized as a function of cytoskeleton disturbance (Egbowon et al., 2016). However, in the present work, we detected that the decrease in RPE cells motility was accompanied by downregulation of fibronectin and E-cadherin in RPE cells. ECM and cell adhesion proteins provide both intercellular communication and cell migration. The imbalance in the location and content of these proteins leads to disturbance in the cell behaviour including their motility. Thus, Cd-caused decrease in fibronectin and E-cadherin contents could be, at least partially, a cause of the decrease in RPE cells motility. Our results are consistent with the data that $\mathrm{Cd}$ can disrupt cadherin-mediated cell-cell adhesion in endothelial cells (Woods et al., 2008). Moreover, the link between E-cadherin expression and inhibition of RPE cells migration in the course of $\mathrm{Cd}$ exposure is presented for the first time. The current study confirmed that curcumin ameliorated the RPE cells motility as well as fibronectin and E-cadherin expression. Therefore, the modulation of RPE adhesiveness could be considered a cytoprotective effect of curcumin.

The effect of curcumin on Cd-caused PARP alteration and parthanatos flux. Genotoxicity of $\mathrm{Cd}$ was studied on various tissues and is well known. However, the detrimental effect of $\mathrm{Cd}$ on repairing cellular systems is poorly understood. In the present study, we examined DNA repair enzyme poly(ADP-ribose) polymerase 1 (PARP-1), one of wide spread enzymes among eukaryotic cells. The results we obtained in our study indicated that the exposure to $10 \mu \mathrm{M} \mathrm{Cd}$ induced the PARP upregu- 
lation. On the other hand, curcumin application inhibited Cd-caused PARP increase. Our results are consistent with earlier presented data on the $\mathrm{Cd}$ effect in the renal epithelial cells and astrocytes (Kushwaha et al., 2018; Luo et al., 2020). PARP can be activated by several genotoxic compounds to bind DNA strand breaks. Activated PARP catalyzes the polyADP-ribosylation of nuclear proteins, which control the chromatin structure and DNA replication. In the recent years, there has been a large amount of data to display the relation of PARP activities with the regulation of cellular response. PARP proteins family also plays important roles in the regulation of transcription, the cellular stress response, mRNA stability, cell division, and protein degradation (Bai, 2015). Furthermore, parthanatos, which is a PARP-1-dependent form of programmed cell death, was discovered in cancer and non-transformed cells (Ma et al., 2016). The upregulation in cleaved-PARP content is the main index of the parthanatos progress. The genotoxic effect of $\mathrm{Cd}$ on PARP-1-dependent parthanatos was determined in osteoblast MC3T3-E1 cell line, renal tubular epithelial NRK-52E cell line and cultured rat astrocytes (Kushwaha et al., 2018; Luo et al., 2020; Ou et al., 2021).

Increasing cleaved-PARP/PARP ratio is considered as a process accompanied by apoptotic changes (Kushwaha et al., 2018). Together with parthanatos, multiple kinases and antioxidants are involved in a response to Cd cytotoxicity while balance in apoptosis, autophagy and parthanatos is extremely instable (So \& Oh, 2016). Furthermore, $\mathrm{Cd}$ can initiate the progress of cell death through mitochondrial damage and synergistic effect caused by the positive feedback between machinery of parthanatos and oxidative stress (Luo et al., 2017). The results we obtained demonstrate that low doses of curcumin are potent to ameliorate PARP activity and prevent harmful effect of PARP overactivation. PARP-1 plays a dual role in genotoxicity. PARP-1 mediates DNA repair when DNA damage is low. However, if DNA damage is severe, PARP can aggravate multiple cell damage and initiate the cell death (So \& Oh, 2016; Luo et al., 2017). Thus, the results presented in our study are evidence that Cd-caused decrease in RPE cells viability could be at least partially initiated with synergetic interaction of parthanatos and oxidative stress.

The effects of curcumin as anti-inflammatory, anti-proliferative and apoptosis initiation agent in malignant cells have been documented over the recent years. However, the efficacy of curcumin to prevent overreactivity of normal glial cells remains unstudied. Exposures to $25-100 \mu \mathrm{M}$ doses of curcumin are efficient to induce the cell death in various cancer cell types. For instance, curcumin was observed as an apoptosis inducer through cleaved PARP-1 upregulation and caspase-3 dependent pathway in lymphoblastic leukaemia cell lines (Mishra et al., 2016). Despite this, similar high doses of curcumin are cytotoxic to most normal cell types. On the contrary, low doses of curcumin administration can stimulate the protective mechanisms in damaged cells (Nedzvetsky et al., 2017, 2018; Ağca, 2019). It was reported that curcumin prevents the apoptosis initiation as well as cleaved PARP production in osteoblasts and adipocytes (Zhu et al., 2015; Chen et al., 2016). Besides, low doses of curcumin exerted cytoprotection in the diabetic retinopathy model while PARP is involved in retinal abnormalities (Platania et al., 2018). Therefore, the protective effect of curcumin could be related, at least partially, to the regulation of PARP activity.

Several reports have confirmed the efficacy of curcumin in retinal cytoprotection. However, the protective effect of curcumin was confirmed for retinal cells in respect with its antioxidant features (Park et al., 2017; Muangnoi et al., 2019; López-Malo et al., 2020). On the other hand, curcumin is potent to affect different vital pathways including autophagy and apoptosis initiation. PARP also causes cell death and plays a dual role in apoptosis through the effects on the intrinsic (mitochondrial-dependent) and extrinsic (death-receptor-dependent) pathways (Zhang et al., 2012). In spite of a number of reports, the mechanism of curcumin-caused PARP inhibition is poorly understood. Curcumin was reported to enhance the susceptibility of poly(ADP-ribose) polymerase to its inhibitors (Choi \& Park, 2015). It is hypothesized that curcumin can regulate the induction of cell death by expression of the autophagy markers Bcl-2 and Bcl-xl, which mediate the functional crosstalk between autophagy and apoptosis (Anto et al., 2002).

Moreover, curcumin is well characterized as an NF- $\mathrm{KB}$ inhibitor (Schwertheim et al., 2017). The direct and indirect PARP and NF-kB interactions could be promising means to mediate the PARP-dependent cytoprotective effect of curcumin as was demonstrated on astrocytes (Nedzvetsky et al., 2018, 2019; Kirici et al., 2019).

The number of proposed effective strategies to prevent Cd-caused retinal damages is extremely limited. Taking together the results obtained in our work, the administration of low doses of soluble curcumin exhibits multiple cytoprotective effect in RPE cells exposed to $\mathrm{Cd}$. In addition, the observed protective effect of curcumin is mediated at least with modulation of PARP-1 activity, E-cadherin, fibronectin and Nrf2 expressions.

\section{Conclusion}

$\mathrm{Cd}$ that is considered a widespread dangerous ecotoxicant decreases viability of RPE cells, which is accompanied by the oxidative stress, depletion of migration, parthanatos, imbalance in adhesiveness, and ECM proteins expression. The administration of soluble curcumin to $\mathrm{Cd}$ stressed RPE cells ameliorated all aforementioned disturbances. Therefore, low doses of soluble curcumin are potent to ameliorate cytotoxic effect of Cd exposure through the suppression of ROS production, parthanatos and restoring RPE cells adhesiveness. The presented results demonstrate that soluble curcumin can be considered a promising protector against $\mathrm{Cd}$-caused retinal injury.

\section{References}

Aberami, S., Nikhalashree, S., Bharathselvi, M., Biswas, J., Sulochana, K. N., \& Coral, K. (2019). Elemental concentrations in Choroid-Rpe and retina of human eyes with age-related macular degeneration. Experimental Eye Research, 186, 107718

Acan, N. L., \& Tezcan, E. F. (1995). Inhibition kinetics of sheep brain glutathione reductase by cadmium ion. Biochemical and Molecular Medicine, 54(1), 33-37.

Ağca, C. A. (2019). Homocysteine-induced damage of cultured glioblastoma cells: Amelioration by curcumin. Neurophysiology, 51(6), 416-423.

Aggarwal, B. B., Sundaram, C., Malani, N., \& Ichikawa, H. (2007). Curcumin: The Indian solid gold. Advances in Experimental Medicine and Biology, 595, 1-75.

Al-Jassabi, S., Ahmed, K. A., \& Abdulla, M. A. (2012). Antioxidant effect of curcumin against microcystin-LR-induced renal oxidative damage in Balb/c mice. Tropical Journal of Pharmaceutical Research, 11(4), 531-536.

Anto, R. J., Mukhopadhyay, A., Denning, K., \& Aggarwal, B. B. (2002). Curcumin (diferuloylmethane) induces apoptosis through activation of caspase-8, BID cleavage and cytochrome $\mathrm{c}$ release: Its suppression by ectopic expression of Bcl-2 and Bcl-xl. Carcinogenesis, 23(1), 143-150.

Bai, P. (2015). Biology of poly(ADP-ribose) polymerases: The factotums of cell maintenance. Molecular Cell, 58(6), 947-958.

Baiomy, A. A., \& Mansour, A. A. (2016). Genetic and histopathological responses to cadmium toxicity in rabbit's kidney and liver: protection by ginger (Zingiber officinale). Biological Trace Element Research, 170(2), 320-329.

Barbosa-Sabanero, K., Hoffmann, A., Judge, C., Lightcap, N., Tsonis, P. A., \& Del Rio-Tsonis, K. (2012). Lens and retina regeneration: New perspectives from model organisms. Biochemical Journal, 447(3), 321-334.

Basnet, P., \& Skalko-Basnet, N. (2011). Curcumin: An anti-inflammatory molecule from a curry spice on the path to cancer treatment. Molecules, 16(6), 45674598.

Bereswill, S., Muñoz, M., Fischer, A., Plickert, R., Haag, L. M., Otto, B., Kühl, A., Loddenkemper, C., Göbel, U., \& Heimesaat, M. M. (2010). Anti-inflammatory effects of resveratrol, curcumin and simvastatin in acute small intestinal inflammation. PloS One, 5(12), e15099.

Bradford, M. M. (1976). A rapid and sensitive method for the quantitation of microgram quantities of protein utilizing the principle of protein-dye binding. Analytical Biochemistry, 72, 248-254.

Branca, J. J. V., Morucci, G., \& Pacini, A. (2018). Cadmium-induced neurotoxicity: Still much ado. Neural Regeneration Research, 13(11), 1879-1882.

Chen, L., Liu, L., \& Huang, S. (2008). Cadmium activates the mitogen-activated protein kinase (MAPK) pathway via induction of reactive oxygen species and inhibition of protein phosphatases $2 \mathrm{~A}$ and 5. Free Radical Biology and Medicine, 45(7), 1035-1044.

Chen, Z., Xue, J., Shen, T., Ba, G., Yu, D., \& Fu, Q. (2016). Curcumin alleviates glucocorticoid-induced osteoporosis by protecting osteoblasts from apoptosis in vivo and in vitro. Clinical and Experimental Pharmacology and Physiology, 43(2), 268-276.

Choi, Y. E., \& Park, E. (2015). Curcumin enhances poly(ADP-ribose) polymerase inhibitor sensitivity to chemotherapy in breast cancer cells. The Journal of Nutritional Biochemistry, 26(12), 1442-1447.

Comet, V., Ouaach, A., Mandiki, S. N. M., Flamion, E., Ferain, A., Van Larebeke, M., Lemaire, B., Reyes López, F. E., Tort, L., Larondelle, Y., \& Kestemont, P. 
(2018). Environmentally-realistic concentration of cadmium combined with polyunsaturated fatty acids enriched diets modulated non-specific immunity in rainbow trout. Aquatic Toxicology, 196, 104-116.

Egbowon, B. F., Harris, W., Arnott, G., Mills, C. L., \& Hargreaves, A. J. (2016). Sub-lethal concentrations of $\mathrm{CdCl}_{2}$ disrupt cell migration and cytoskeletal proteins in cultured mouse TM4 Sertoli cells. Toxicology in Vitro, 32, 154-165.

Farina, M., Avila, D. S., Da Rocha, J. B. T., \& Aschner, M. (2013). Metals, oxidative stress and neurodegeneration: A focus on iron, manganese and mercury. Neurochemistry International, 62(5), 575-594.

Fattori, V., Pinho-Ribeiro, F. A., Borghi, S. M., Alves-Filho, J. C., Cunha, T. M., Cunha, F. Q., Casagrande, R., \& Verri, W. A. (2015). Curcumin inhibits superoxide anion-induced pain-like behavior and leukocyte recruitment by increasing $\mathrm{Nrf} 2$ expression and reducing NF- $\mathrm{BB}$ activation. Journal of Inflammation Research, 64(12), 993-1003.

Fujiwara, Y., Lee, J. Y., Tokumoto, M., \& Satoh, M. (2012). Cadmium renal toxicity via apoptotic pathways. Biological and Pharmaceutical Bulletin, 35(11), $1892-1897$.

García-Niño, W. R., \& Pedraza-Chaverrí, J. (2014). Protective effect of curcumin against heavy metals-induced liver damage. Food and Chemical Toxicology, $69,182-201$

Gulisano, M., Pacini, S., Punzi, T., Morucci, G., Quagliata, S., Delfino, G., Sarchielli, E., Marini, M., \& Vannelli, G. B. (2009). Cadmium modulates proliferation and differentiation of human neuroblasts. Journal of Neuroscience Research, 87(1), 228-237.

Hatcher, H., Planalp, R., Cho, J., Torti, F. M., \& Torti, S. V. (2008). Curcumin: From ancient medicine to current clinical trials. Cellular and Molecular Life Sciences, 65(11), 1631-1652.

Hollborn, M., Chen, R., Wiedemann, P., Reichenbach, A., Bringmann, A., \& Kohen, L. (2013). Cytotoxic effects of curcumin in human retinal pigment epithelial cells. PLoS One, 8(3), e59603.

Huang, Y. C., Chao, K. S., Liao, H. F., \& Chen, Y. J. (2013). Targeting sonic hedgehog signaling by compounds and derivatives from natural products. EvidenceBased Complementary and Alternative Medicine, 2013, 748587.

Im, J. Y., Paik, S. G., \& Han, P. L. (2006). Cadmium-induced astroglial death proceeds via glutathione depletion. Journal of Neuroscience Research, 83(2), 301-308.

Järup, L., \& Åkesson, A. (2009). Current status of cadmium as an environmental health problem. Toxicology and Applied Pharmacology, 238(3), 201-208.

Kalariya, N. M., Wills, N. K., Ramana, K. V., Srivastava, S. K., \& van Kuijk, F. J. (2009). Cadmium-induced apoptotic death of human retinal pigment epithetlial cells is mediated by MAPK pathway. Experimental Eye Research, 89(4), 494-502.

Kar, F., Hacioglu, C., Uslu, S., \& Kanbak, G. (2019). Curcumin acts as post-protective effects on rat hippocampal synaptosomes in a neuronal model of aluminum-induced toxicity. Neurochemical Research, 44(8), 2020-2029.

Kirici, M., Nedzvetsky, V. S., Agca, C. A., \& Gasso, V. Y. (2019). Sublethal doses of copper sulphate initiate deregulation of glial cytoskeleton, NF-kB and PARP expression in Capoeta umbla brain tissue. Regulatory Mechanisms in Biosystems, 10(1), 103-110.

Klettner, A. (2012). Oxidative stress induced cellular signaling in RPE cells. Frontiers in Bioscience, 4(2), 392-411.

Kolluru, G. K., Tamilarasan, K. P., Priya, S. G., Durgha, N. P., \& Chatterjee, S. (2006). Cadmium induced endothelial dysfunction: consequence of defective migratory pattern of endothelial cells in association with poor nitric oxide availability under cadmium challenge. Cell Biology International, 30(5), 427-438.

Kushwaha, R., Mishra, J., Tripathi, S., Khare, P., \& Bandyopadhyay, S. (2018). Arsenic, cadmium, and lead like troglitazone trigger PPAR $\gamma$-dependent poly (ADP-ribose) polymerase expression and subsequent apoptosis in rat brain astrocytes. Molecular Neurobiology, 55(3), 2125-2149.

Kutluay, S. B., Doroghazi, J., Roemer, M. E., \& Triezenberg, S. J. (2008). Curcumin inhibits herpes simplex virus immediate-early gene expression by a mechanism independent of p300/CBP histone acetyltransferase activity. Virology, 373(2), 239-247.

Lee, J. Y., Tokumoto, M., Hattori, Y., Fujiwara, Y., Shimada, A., \& Satoh, M. (2016). Different regulation of p53 expression by cadmium exposure in kidney, liver, intestine, vasculature, and brain astrocytes. Toxicological Research, 32(1) 73-80.

Liu, F., Wang, B., Li, L., Dong, F., Chen, X., Li, Y., Dong, X., Wada, Y., Kapron, C., \& Liu, J. (2015). Low-dose cadmium upregulates VEGF expression in lung adenocarcinoma cells. International Journal of Environmental Research and Public Health, 12(9), 10508-10521.

López-Malo, D., Villarón-Casares, C. A., Alarcón-Jiménez, J., Miranda, M., DíazLlopis, M., Romero, F. J., \& Villar, V. M. (2020). Curcumin as a therapeutic option in retinal diseases. Antioxidants, $9(1), 48$.

Luo, T., Yu, Q., Zou, H., Zhao, H., Gu, J., Yuan, Y., \& Liu, Z. (2020). Role of poly (ADP-ribose) polymerase-1 in cadmium-induced cellular DNA damage and cell cycle arrest in rat renal tubular epithelial cell line NRK-52E. Environmental Pollution, 261, 114149 .
Luo, T., Yuan, Y., Yu, Q., Liu, G., Long, M., Zhang, K., Bian, J., Gu, J., Zou, H., Wang, Y., Zhu, J., Liu, X., \& Liu, Z. (2017). PARP-1 overexpression contributes to cadmium-induced death in rat proximal tubular cells via parthanatos and the MAPK signalling pathway. Scientific Reports, 7(1), 1-13.

Ma, D., Lu, B., Feng, C., Wang, C., Wang, Y., Luo, T., Feng, J., Jia, H., Chi, G., Luo, Y., \& Ge, P. (2016). Deoxypodophyllotoxin triggers parthanatos in glioma cells via induction of excessive ROS. Cancer Letters, 371(2), 194-204.

Marlowe, M., Errera, J., \& Jacobs, J. (1983). Increased lead and cadmium burdens among mentally retarded children and children with borderline intelligence. American Journal of Mental Deficiency, 87(5), 477-483.

Mishra, D., Singh, S., \& Narayan, G. (2016). Curcumin induces apoptosis in Pre-B acute lymphoblastic leukemia cell lines via PARP-1 cleavage. Asian Pacific Journal of Cancer Prevention, 17(8), 3865-3869.

Mohajeri, M., Rezaee, M., \& Sahebkar, A. (2017). Cadmium-induced toxicity is rescued by curcumin: A review. Biofactors, 43(5), 645-661.

Momeni, H. R., \& Eskandari, N. (2020). Curcumin protects the testis against cadmium-induced histopathological damages and oxidative stress in mice. Human and Experimental Toxicology, 39(5), 653-661.

Mori, H., Sasaki, G., Nishikawa, M., \& Hara, M. (2015). Effects of subcytotoxic cadmium on morphology of glial fibrillary acidic protein network in astrocytes derived from murine neural stem/progenitor cells. Environmental Toxicology and Pharmacology, 40(2), 639-644.

Muangnoi, C., Sharif, U., Ratnatilaka Na Bhuket, P., Rojsitthisak, P., \& Paraoan, L. (2019). Protective effects of curcumin ester prodrug, curcumin diethyl disuccinate against $\mathrm{H}_{2} \mathrm{O}_{2}$-induced oxidative stress in human retinal pigment epithelial cells: Potential therapeutic avenues for age-related macular degeneration. International Journal of Molecular Sciences, 20(13), 3367.

Nair, A. R., DeGheselle, O., Smeets, K., Van Kerkhove, E., \& Cuypers, A. (2013). Cadmium-induced pathologies: Where is the oxidative balance lost (or not)? International Joumal of Molecular Sciences, 14(3), 6116-6143.

Namgyal, D., Ali, S., Mehta, R., \& Sarwat, M. (2020). The neuroprotective effect of curcumin against $\mathrm{Cd}$-induced neurotoxicity and hippocampal neurogenesis promotion through CREB-BDNF signaling pathway. Toxicology, 442, 152542

Nedzvetsky, V. S., Agca, C. A., \& Kyrychenko, S. V. (2017). Neuroprotective effect of curcumin on LPS-activated astrocytes is related to the prevention of GFAP and NF- $\mathrm{kB}$ upregulation. Neurophysiology, 49(4), 305-307.

Nedzvetsky, V. S., Sukharenko, E. V., Baydas, G., \& Andrievsky, G. V. (2019). Water-soluble $\mathrm{C}_{60}$ fullerene ameliorates astroglial reactivity and TNFa production in retina of diabetic rats. Regulatory Mechanisms in Biosystems, 10(4), 513-519.

Nedzvetsky, V. S., Sukharenko, E. V., Kyrychenko, S. V., \& Baydas, G. (2018). Soluble curcumin prevents cadmium cytotoxicity in primary rat astrocytes by improving a lack of GFAP and glucose-6-phosphate-dehydrogenase. Regulatory Mechanisms in Biosystems, 9(4), 501-507.

Ninkov, M., Aleksandrov, A. P., Demenesku, J., Mirkov, I., Mileusnic, D., Petrovic, A., Grigorov, I., Zolotarevski, L., Tolinacki, M., Kataranovski, D., Brceski, I., \& Kataranovski, M. (2015). Toxicity of oral cadmium intake: Impact on gut immunity. Toxicology Letters, 237(2), 89-99.

Ou, L., Wang, H., Wu, Z., Wang, P., Yang, L., Li, X., Sun, K., Zhu, X., \& Zhang, R. (2021). Effects of cadmium on osteoblast cell line: Exportin 1 accumulation, $\mathrm{p}$ INK activation, DNA damage and cell apoptosis. Ecotoxicology and Environmental Safety, 208, 111668

Pamphlett, R., Cherepanoff, S., Too, L. K., Kum Jew, S., Doble, P. A., \& Bishop, D. P. (2020). The distribution of toxic metals in the human retina and optic nerve head: Implications for age-related macular degeneration. PloS One, 15(10), e0241054.

Park, S. I., Lee, E. H., Kim, S. R., \& Jang, Y. P. (2017). Anti-apoptotic effects of Curcuma longa $\mathrm{L}$. extract and its curcuminoids against blue light-induced cytotoxicity in A2E-laden human retinal pigment epithelial cells. Journal of Pharmacy and Pharmacology, 69(3), 334-340.

Phuagkhaopong, S., Ospondpant, D., Kasemsuk, T., Sibmooh, N., Soodvilai, S., Power, C., \& Vivithanaporn, P. (2017). Cadmium-induced IL-6 and IL-8 expression and release from astrocytes are mediated by MAPK and NF-кB pathways. Neurotoxicology, 60, 82-91.

Pihl, R. O., \& Parkes, M. (1977). Hair element content in learning disabled children Science, 198(4313), 204-206.

Platania, C., Fidilio, A., Lazzara, F., Piazza, C., Geraci, F., Giurdanella, G., Leggio, G. M., Salomone, S., Drago, F. \& Bucolo, C. (2018). Retinal protection and distribution of curcumin in vitro and in vivo. Frontiers in Pharmacology, 9, 670.

Poliandri, A. H., Cabilla, J. P., Velardez, M. O., Bodo, C. C., \& Duvilanski, B. H. (2003). Cadmium induces apoptosis in anterior pituitary cells that can be reversed by treatment with antioxidants. Toxicology and Applied Pharmacology, 190(1), 17-24.

Priyadarsini, K. I. (2014). The chemistry of curcumin: From extraction to therapeutic agent. Molecules, 19(12), 20091-20112.

Pulido, G., Treviño, S., Brambila, E., Vazquez-Roque, R., Moreno-Rodriguez, A., Rosas, U. P., Handal, S. A., Guevara, J. F., \& Diaz, A. (2019). The administra- 
tion of cadmium for 2, 3 and 4 months causes a loss of recognition memory, promotes neuronal hypotrophy and apoptosis in the hippocampus of rats. Neurochemical Research, 44(2), 485-497.

Purkayastha, S., Berliner, A., Fernando, S. S., Ranasinghe, B., Ray, I., Tariq, H., \& Banerjee, P. (2009). Curcumin blocks brain tumor formation. Brain Research, $1266,130-138$

Satarug, S., Kikuchi, M., Wisedpanichkij, R., Li, B., Takeda, K., Na-Bangchang, K., Moore, M. R., Hirayama, K., \& Shibahara, S. (2008). Prevention of cadmium accumulation in retinal pigment epithelium with manganese and zinc. Experimental Eye Research, 87(6), 587-593.

Schwertheim, S., Wein, F., Lennartz, K., Worm, K., Schmid, K. W., \& Sheu-Grabellus, S. Y. (2017). Curcumin induces G2/M arrest, apoptosis, NF-kB inhibition, and expression of differentiation genes in thyroid carcinoma cells. Journal of Cancer Research and Clinical Oncology, 143(7), 1143-1154.

Shukla, G. S., Hussain, T., Srivastava, R. S., \& Chandra, S. V. (1989). Glutathione peroxidase and catalase in liver, kidney, testis and brain regions of rats following cadmium exposure and subsequent withdrawal. Industrial Health, 27(2), 59-69.

So, K. Y., \& Oh, S. H. (2016). Cadmium-induced heme-oxygenase-1 expression plays dual roles in autophagy and apoptosis and is regulated by both $\mathrm{PKC}-\delta$ and PKB/Akt activation in NRK52E kidney cells. Toxicology, 370, 49-59.

Strasser, E. M., Wessner, B., Manhart, N., \& Roth, E. (2005). The relationship between the anti-inflammatory effects of curcumin and cellular glutathione content in myelomonocytic cells. Biochemical Pharmacology, 70(4), 552-559.

Świergosz-Kowalewska, R. (2001). Cadmium distribution and toxicity in tissues of small rodents. Microscopy Research and Technique, 55(3), 208-222.

Tajbakhsh, S., Mohammadi, K., Deilami, I., Zandi, K., Fouladvand, M., Ramedani, E., \& Asayesh, G. (2008). Antibacterial activity of indium curcumin and indium diacetylcurcumin. African Journal of Biotechnology, 7(21), 3832-3835.

Tandon, S. K., Singh, S., Prasad, S., Khandekar, K., Dwivedi, V. K., Chatterjee, M., \& Mathur, N. (2003). Reversal of cadmium induced oxidative stress by chelating agent, antioxidant or their combination in rat. Toxicology Letters, 145(3), 211-217.

Thatcher, R. W., Lester, M. L., McAlaster, R., \& Horst, R. (1982). Effects of low levels of cadmium and lead on cognitive functioning in children. Archives of Environmental Health, 37(3), 159-166.

Tian, S., Lu, L., Zhang, J., Wang, K., Brown, P., He, Z., Liang, L., \& Yang, X. (2011). Calcium protects roots of Sedum alfredii $\mathrm{H}$. against cadmium-induced oxidative stress. Chemosphere, 84(1), 63-69.

Tong, W., Wang, Q., Sun, D., \& Suo, J. (2016). Curcumin suppresses colon cancer cell invasion via AMPK-induced inhibition of NF- $\mathrm{kB}$, uPA activator and MMP9. Oncology Letters, 12(5), 4139-4146.
Van Maele-Fabry, G., Lombaert, N., \& Lison, D. (2016). Dietary exposure to cadmium and risk of breast cancer in postmenopausal women: A systematic review and meta-analysis. Environment International, 86, 1-13.

Vanlaeys, A., Fouquet, G., Kischel, P., Hague, F., Pasco-Brassart, S., Lefebvre, T., Rybarczyk, P., Dhennin-Duthille, I., Brassart, B., Ouadid-Ahidouch, H., \& Gautier, M. (2020). Cadmium exposure enhances cell migration and invasion through modulated TRPM7 channel expression. Archives of Toxicology, 94(3), 735-747.

Wang, B., \& Du, Y. (2013). Cadmium and its neurotoxic effects. Oxidative Medicine and Cellular Longevity, 2013, 898034.

Wang, L., Li, C., Guo, H., Kern, T. S., Huang, K., \& Zheng, L. (2011). Curcumin inhibits neuronal and vascular degeneration in retina after ischemia and reperfusion injury. PLoS One, 6(8), e23194.

Wang, L., Shen, Y., Song, R., Sun, Y., Xu, J., \& Xu, Q. (2009). An anticancer effect of curcumin mediated by down-regulating phosphatase of regenerating liver-3 expression on highly metastatic melanoma cells. Molecular Pharmacology, 76(6), 1238-1245.

Wang, Y., Wang, X., Zhang, L., \& Zhang, R. (2018). Alleviation of acute lung injury in rats with sepsis by resveratrol via the phosphatidylinositol 3-kinase/nuclear factor-erythroid 2 related factor 2/heme oxygenase-1 (PI3K/Nrf2/HO-1) pathway. Medical Science Monitor, 24, 3604-3611.

Wei, Z., \& Shaikh, Z. A. (2017). Cadmium stimulates metastasis-associated phenotype in triple-negative breast cancer cells through integrin and $\beta$-catenin signaling. Toxicology and Applied Pharmacology, 328, 70-80.

Wills, N. K., Kalariya, N., Sadagopa Ramanujam, V. M., Lewis, J. R., Haji Abdollahi, S., Husain, A., \& van Kuijk, F. J. G. M. (2009). Human retinal cadmium accumulation as a factor in the etiology of age-related macular degeneration. Experimental Eye Research, 89(1), 79-87.

Woods, J. M., Leone, M., Klosowska, K., Lamar, P. C., Shaknovsky, T. J., \& Prozialeck, W. C. (2008). Direct antiangiogenic actions of cadmium on human vascular endothelial cells. Toxicology in Vitro, 22(3), 643-651.

Zhang, F., Lau, S. S., \& Monks, T. J. (2012). A dual role for poly(ADP-ribose) polymerase-1 during caspase-dependent apoptosis. Toxicological Sciences, 128(1), 103-114.

Zhang, L., Xia, Q., Zhou, Y., \& Li, J. (2019). Endoplasmic reticulum stress and autophagy contribute to cadmium-induced cytotoxicity in retinal pigment epithelial cells. Toxicology Letters, 311, 105-113.

Zhu, L., Han, M. B., Gao, Y., Wang, H., Dai, L., Wen, Y., \& Na, L. X. (2015). Curcumin triggers apoptosis via upregulation of $\mathrm{Bax} / \mathrm{Bcl}-2$ ratio and caspase activation in SW872 human adipocytes. Molecular Medicine Reports, 12(1), 1151-1156. 